\title{
Variation of Splice Length with Bending Behavior of Reinforced Concrete Beams
}

\author{
Sulastri $^{1 *}$, Ilham Nurhuda $^{2}$ and Antonius ${ }^{3}$ \\ ${ }^{I}$ Master of Civil Engineering, Faculty of Engineering, Diponegoro University, Jl. Prof. H. Soedarto, SH, \\ Tembalang, Semarang 50275, Indonesia \\ ${ }^{2}$ Civil Engineering Department, Faculty of Engineering, Diponegoro University, Jl. Prof. H. Soedarto, \\ SH, Tembalang, Semarang 50275, Indonesia \\ ${ }^{3}$ Universitas Islam Sultan Agung, Jl. Raya Kaligawe km.4 Semarang 50112, Indonesia \\ *Corresponding author: sulastriskandar@gmail.com
}

(Received: April 28 ${ }^{\text {th }}, 2019$; Revised: July $14^{\text {th }}, 2019$; Accepted: August, $1^{\text {st }}$ 2019)

\begin{abstract}
The splice length of the distribution depends on the concrete stress with reinforcement, generally the bond stress is tested by pull out testing where pull out testing can provide a good comparison between the efficiency of the attachment of various types of reinforcement surfaces. However, the bending behavior of the beam is very different from the pure tensile pull out test. This study presents the effects of variations of lap splice $(30 \mathrm{db}$, and $40 \mathrm{db})$ in the area of beam pull. The first test object was a beam BN - 0 (non splice length) which was a normal beam. The second test object was a beam BN - 30db with the splices length $(l d)$ of $480 \mathrm{~mm}$ and the third test object was a $40 \mathrm{db}$ beam with the splice length $(l d)$ of $640 \mathrm{~mm}$. The test used a pure bending test method with loading of Two Point Loads on a simple support beam. The results gained from this study obtained flexural capacity in BN-0 (non lap splices) of $115.15 \mathrm{kN}$, flexural capacity of $\mathrm{BN}-30 d b$ of $90.484 \mathrm{kN}$, and beam flexural capacity of BN$40 \mathrm{db}$ of $124.848 \mathrm{kN}$. The displacement ductility at BN-30 db decreased $35 \%$ to $\mathrm{BN}-0$ and displacement ductility at $\mathrm{BN}-40 \mathrm{db}$ increased $48 \%$ to $\mathrm{BN}-0$, the bond strength attached to $\mathrm{BN}-40 \mathrm{db}$ increased $2.92 \%$ to BN-30db. The splice length $\left(l_{d}\right) 40 d b$ was able to develop the ability to achieve yield stress loads and the spread of crack concentration around the joints.
\end{abstract}

Keywords: splice length; bond strength; tension; displacement ductility

\section{Introduction}

Generally the limitations of the reinforcement length needed on reinforcing works are often longer than the available reinforcing steel so that reinforcement joints are needed [2-5]. In reinforced concrete construction, the connection functions as a transfer of force and the splice length is related to the length of the stress distribution $\left(l_{d}\right)$ increases with increasing stress. SNI 2847: 2013 [1] provides a guideline for calculating the length of distribution depending on the bonding stress of concrete with reinforcement ( ). This fixed stress is usually tested by pull out testing. This testing can provide a good comparison between the adhesion efficiency of various types of reinforcement surfaces, but the frame structure has not been able to provide real sticky stress so that the bending behavior of the beam is very different from the pure tensile test pull out.

From the background of the above problems, it is necessary to do research on "Variations in the lap splice of the tensile distribution of bending conditions of beams in reinforced concrete bond stresses". In this research deformed reinforcement used bars D16 $\mathrm{mm}$ for tensile zone, plain 
reinforced bars $\varnothing 10 \mathrm{~mm}$ compressive reinforcement and plain reinforced bars $\varnothing 8 \mathrm{~mm}$ for shear reinforcement. The review is carried out only on the bending behavior of the tensile area and the test is carried out with a beam splice.

\section{Theoretical Basis}

The main basis of the long distribution theory is to take into account reinforcing steel embedded in concrete masses [7-8]. The P force is applied to reinforcing steel, the force will be held between reinforcing steel and surrounding concrete and the tensile force that can be resisted by reinforcement with reinforced concrete.

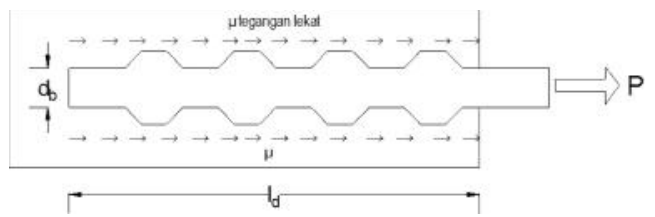

Fig. 1. Balance of $\mathrm{P}$ force in reinforcing steel with concrete

$$
P=\mu . l_{d} \pi \cdot d_{b}
$$

With the capacity of steel accepting tensile forces:

$$
P=\frac{1}{4} \pi \cdot d_{b}^{2} \cdot f y
$$

So that the splice length distribution $\left(l_{d}\right)$

$$
l_{d}=\frac{a_{b} \cdot J_{y}}{4 . \mu}
$$

With an average bond strength equation:

$$
\mu=\frac{P}{\pi \cdot d_{b} \cdot l_{d}}
$$

The lap splices of distribution is related to the strong inter-reinforcement bond with concrete which is influenced by several factors i.e: concrete cover, concrete compressive strength, the shape of the concrete surface, reinforcement distance and reinforcement restraints.

Based on SNI 2847: 2013 [1] that the tensile strength of the reinforcement in each cross section of the concrete structure components must be channeled to each section through the naming length, hook, head-headed screw or mechanical device, or a combination therefore, so that the threaded rod length D19 or more small can be calculated by Eq:

$$
l_{d}=\left(\frac{f_{y} \psi_{t} \psi_{e}}{2.1 \sqrt{f_{c}^{\prime}}}\right) d_{b}
$$

with :

$l_{d b}=$ Lap splice $(\mathrm{mm})$

$d_{b}=$ Nominal diameter of the bar $\left(\mathrm{mm}^{2}\right)$

$f_{y}=$ Yield strength of the bar $(\mathrm{MPa})$

$f^{\prime}{ }_{c}=$ Compressive strength of the concrete $(\mathrm{MPa})$

$\psi_{t}=$ Location of reinforcement factors

$\psi_{e}=$ coating factor 


\subsection{Concrete and reinforcing steel bonding mechanism}

According to Park \& Pauly [8], the adhesion stress is the shear stress on the concrete surface and the place where the load is transferred between the reinforcing steel and the surrounding concrete thus changing the reinforcing steel stress.

Nuroji [9] The attachment mechanism between concrete and steel is influenced by several factors, namely: adhesion, friction and interlocking. Some collapse patterns in attachment to the sticky stress test can be shown by events namely splitting failure, pull out failure / slip, failure transfer and reinforcement, reaching, melting and finally breaking followed by reduction in reinforcement diameter.

\subsection{Displacement ductility}

Displacement Ductility is a condition of the comparison between the maximum displacement of the beam and the first displacement that occurs during the yield strength of the bar.

$$
\Delta_{\delta}=\frac{\delta_{u}}{\delta_{y}}
$$

Where :

${ }_{\delta}=$ displacement Ductility

$\delta_{u}=$ maximum displacement

$\delta_{y}=$ yield displacement

\section{Methodology}

The test beam was made of reinforced concrete with compressive strength concrete $f^{\prime} c=27$ $\mathrm{MPa}$. The test beam had a square section with a width of $150 \mathrm{~mm}$, height of $250 \mathrm{~mm}$ and span of $2200 \mathrm{~mm}$ with tensile reinforcement with a diameter of bar $16 \mathrm{~mm}$ (2D16). The tensile strength used was deformed reinforcement bars with a yield stress $(f y)$ of $430 \mathrm{MPa}$.

Table 1. Specimen

\begin{tabular}{lc}
\hline \multicolumn{1}{c}{ Specimens } & Splice length \\
\hline BN-0 & Non splice length \\
\hline BN-30d & $480 \mathrm{~mm}$ \\
\hline BN-40 d & $640 \mathrm{~mm}$ \\
\hline
\end{tabular}

Table 2. Variations in splice length test specimens

\begin{tabular}{lccc}
\hline \multicolumn{1}{c}{ Specimens } & $f^{\prime}{ }_{c}(\mathrm{MPa})$ & $\mathrm{d}_{\mathrm{b}}(\mathrm{mm})$ & $l_{d}(\mathrm{~mm})$ \\
\hline BN-0 non splice length & 27 & 16 & - \\
\hline BN-30 $d_{b}$ & 27 & 16 & 480 \\
\hline BN-40 $d_{b}$ & 27 & 16 & 640 \\
\hline
\end{tabular}




\section{The specimens explained below.}

- Specimen BN-0 (Non splice length).

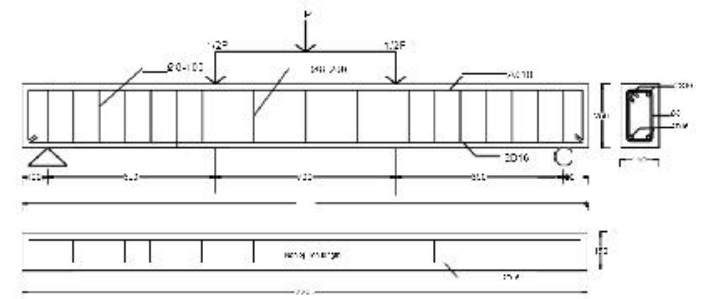

Fig. 2. Specimen and upper BN-0 non splice length

- Specimen BN-30d $d_{b}$ with splice length $480 \mathrm{~mm}$

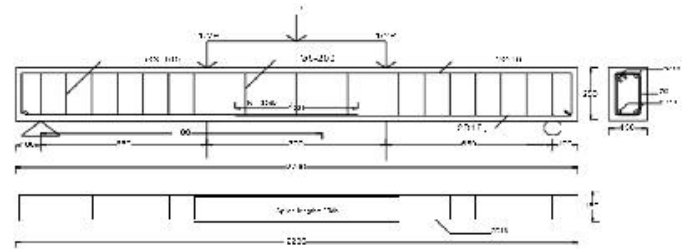

Fig. 3. Specimen and upper BN-30d

- Specimen BN-40db with splice length $640 \mathrm{~mm}$

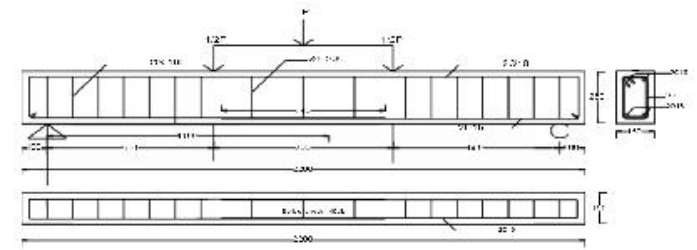

Fig. 4. Specimen and upper BN-40d

\subsection{Installation of Strain Gauge}

The installation of strain gauge on the beam cross section was done to determine the magnitude of the strain that occurred. There were two types of starain gauge used, namely type FLA-60-11 to determine the strain placed on the surface of the reinforcement in the junction area, the installation was done before casting and type PL-60-11 to determine the concrete strain placed on the side surface in the upper press area. Installation of strain gauge on concrete was carried out after casting. The area to be installed by the strain gauge had to be flat and smooth and based on the installation procedure, the strain gauge was connected to the data logger to read the strain value and the LVDT installation in the middle of the span to read the deformation value. Installation of strain gauge on the test object was as follows:

1) Beams of specimens $\mathrm{BN}-0$ was a control beam. The control beam was compared with the data from the test beams with varying lengths of distribution, so that differences could be found. 1 strain gauge was installed on compressed fibers $\left(\begin{array}{c}s \\ s\end{array}\right), 1$ strain gauge was installed on tensile reinforcement $(s)$, and 1 concrete strain was installed on compressive fibers to obtain strain values in compressed concrete. The results of steel reinforcement tensile strain values could be used to graph $(P-)$, so that the behavior of steel reinforcement during loading took place and conditions when the reinforcement began to melt could be seen.

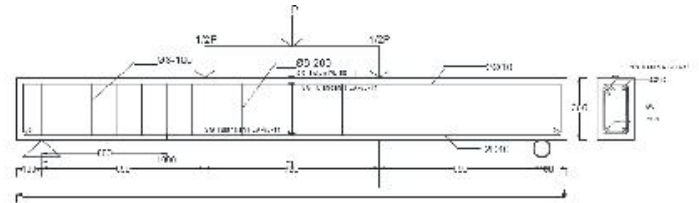

Fig. 5. Detail Placement of BN-0 Strain Gauge non lap splice 
2) Beams of specimens $B N-30 d_{b}$ and $B N-40 d_{b}$ were beams with varying lengths of distribution. 1 strain gauge was installed on press reinforcement $\left({ }_{s}^{\prime}\right), 3$ strain gauges were installed on tensile reinforcement $\left({ }_{s}\right)$ to obtain tensile strain values and 1 concrete strain was mounted on compressive fibers to obtain strain on compressed concrete. The results of the tensile strength of steel reinforcement could be used to graph $(P-)$, so that the behavior of steel reinforcement during loading took place and the conditions when the reinforcement began to yield.

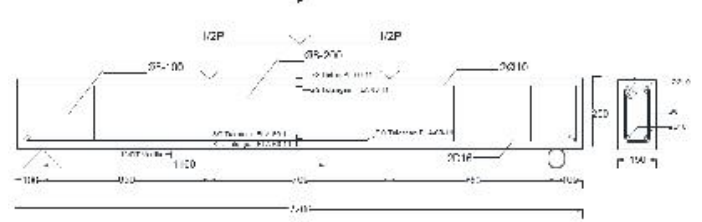

Fig. 6. Detail Placement of Strain Gauge BN - 30d $\mathrm{d}_{\mathrm{b}} \& \mathrm{BN}-40 \mathrm{~d}_{\mathrm{b}}$

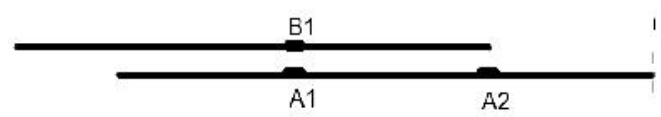

Fig. 7. Strain gauge placement notation on reinforcement tensile BN - 30d $d_{b} \& \mathrm{BN}-40 d_{b}$

\subsection{Implementation of casting}

Concrete Ready Mix with the planned compressive strength $f^{\prime} c$ of $27 \mathrm{MPa}$ used in the manufacture of specimens was originated from PT. Jati Kencana Beton. Casting was done at the Diponegoro University Materials Laboratory. Fresh concrete mix with quality $f^{\prime} c 27 \mathrm{MPa}$ was put into the formwork which has been filled with reinforcement assemblies in one mixer truck mix. Previously, the control test was carried out with a slump test, then a cylindrical specimen was made for a compressive test, after the concrete mixture was in one third, compaction was carried out to prevent air cavities.

\subsection{Curing of specimens}

Treatment was done by covering the test beam with a gunny sack and watering it so that no cracks and evaporation occurred on the test beam, and the cylindrical specimen was opened 24 hours later and immersed in a water bath until testing.

\subsection{Test Procedures and Instrumentation}

The test used a pure bending test method with loading of Two Point Loads on a simple support beam. Reinforced beam test objects were placed on the loading frame. Testing the test object was carried out by giving a monotonic load on the test object. Loading was done with the help of a hydraulic pump and loading was carried out at two points with a distance of $700 \mathrm{~mm}$ between the loading point and as far as $650 \mathrm{~mm}$ from each support. Both sides and models of reinforced concrete beams had a roll-joint support. LVDT placement in the middle of the span determined the maximum deflection that occurred in the beam of the test object.

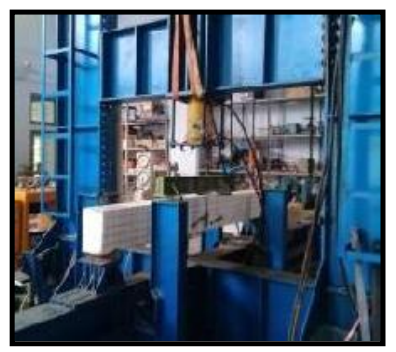

Fig. 9. Setting Up Testing of Reinforced Concrete Beam Test Objects 


\section{Result and Discussion}

\subsection{Testing of Steel Tensile Strength}

The testing procedure was carried out according to ASTM E8 (Standard Test Method for Tension of Metallic Materials). Test specimens were in the form of smooth reinforcement bars 8 $\mathrm{mm}$ in diameter, $10 \mathrm{~mm}$ in diameter and deformed reinforcement bars D16 mm, 2 pieces each. Testing was done by Universal Testing Machine (UTM) in the Material Laboratory and Civil Engineering Construction of Diponegoro University.

From the test results, the yield stress was $\varnothing 8 \mathrm{~mm}, f y=324.50 \mathrm{MPa}$, the ultimate stress was average $f_{u}=450.72 \mathrm{MPa}$. For smooth reinforcement bars $\varnothing 10 \mathrm{~mm} f y=298.45 \mathrm{MPa}$, the ultimate stress was average $f_{u}=434 \mathrm{MPa}$. For deformed reinforcement bars D16 mm $f_{y}=$ $429.93 \mathrm{MPa}$, the ultimate stress was average $f_{u}=605,125 \mathrm{MPa}$. Modulus of elasticity $\left(E_{S}\right)$ of reinforced steel $=200,000 \mathrm{MPa}$.

\subsection{Test Results of Beam}

\subsubsection{Normal concrete beam without splice length (BN - 0 )}

The normal beam test results $\mathrm{BN}-0$ resulted in collapse according to the collapse plan, the first crack on normal beam BN-0 occurred when the load reached $14.74 \mathrm{kN}$. Cracks increased in size according to the increase in load until the beam had collapsed, the maximum load test results on the $\mathrm{BN}-0$ beam were $115.41 \mathrm{kN}$.

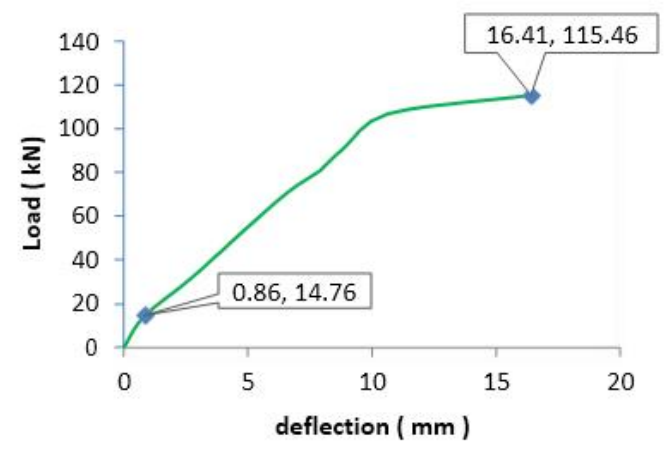

Fig. 10. Load - deflection curve beam spesimen (BN-0)

The curve of the load relation to deflection in beam test BN-0 can be seen in Figure. 10 above, illustrating the behavior of the relationship between load and deflection. When the load was $14.76 \mathrm{kN}$ the beam had the greatest stiffness with a relatively small deflection, this was because the concrete was still sturdy withstand tensile stress that occurred in the beam. When the load of $14.76 \mathrm{kN}$ was $0.86 \mathrm{~mm}$, the first crack started, the first crack event was possible because the cracks that occurred were not too large so that the deflection that occurred was not too large and cracks continued to occur in the flexible area.

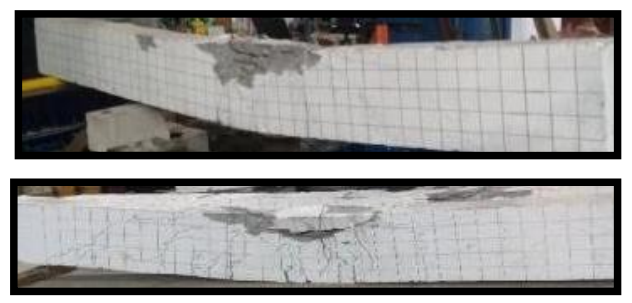

Fig. 11. Crack and crack pattern 


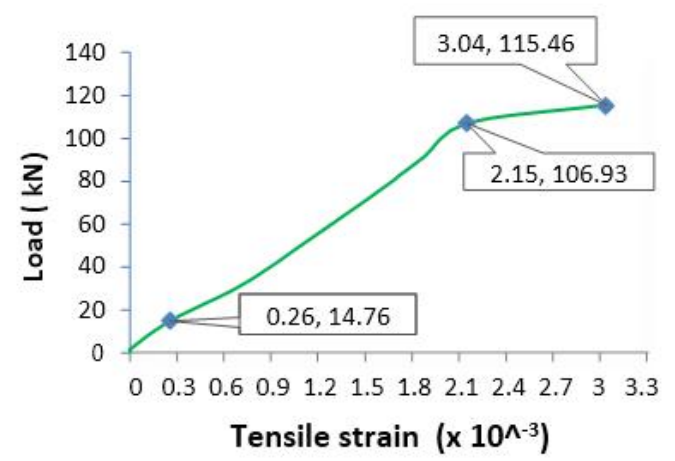

Fig. 12. Load - longitudinal reinforcement tensile strain curve

The curve of the load relationship to the strain of the lower longitudinal pull on the beam specimen BN-0 can be seen in Figure 12 above illustrating the behavior of the relationship between the loads to the tensile strain for the lower longitudinal reinforcement. The position of the yield reinforcement was obtained by comparing the recorded strain values, at $P$ of $14.76 \mathrm{kN}$, had a value of 0.00026 , while at $\mathrm{P}$ of $106.93 \mathrm{kN}$, it had a value of $s$ of 0.00215 and the iron reinforcement which had yielded, at $\mathrm{P}$ of $115.46 \mathrm{kN}$ had the ultimate $s$ value of 0.003 . When the load reached $\mathrm{P}$ of $106.93 \mathrm{kN}$, the interlocking of concrete reinforcement started to play a role in resisting the tensile stress that occurred. The distribution of force transfer from steel reinforcement to concrete was carried out by bars / rib reinforcement.

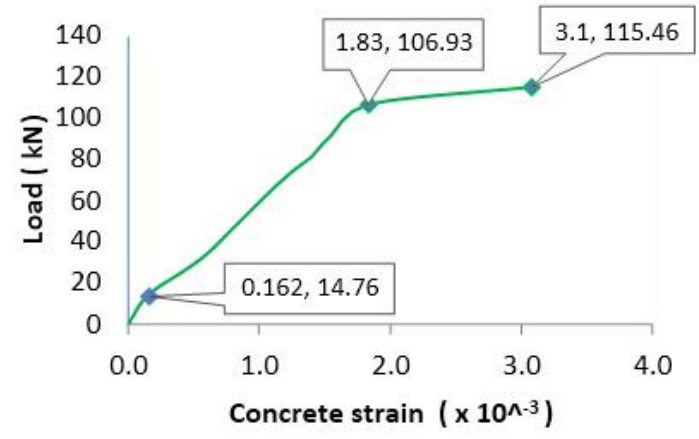

Fig. 13. Load - concrete strain curve

From Figure 13 it can be seen that the concrete strain load showed the concrete strain value was received by the concrete, the load-strain curve was influenced by the first crack that occurred. First crack occurred when $P$ was $14.76 \mathrm{kN}$ with a concrete strain of 0.0002 , when $P$ load of $106.93 \mathrm{kN}$ had a concrete strain of 0.0018 and when the ultimate $P$ load was 115.46 , the concrete strain $\mathrm{kN}$ was 0.0031 .

\subsubsection{Concrete beam with splice length $30 d b(\mathrm{BN}-30 d b)$}

In the BN-30 $d b$ beam, the first crack occurred when the load reached $22.21 \mathrm{kN}$. The test results obtained a maximum load value of $90.848 \mathrm{kN}$.

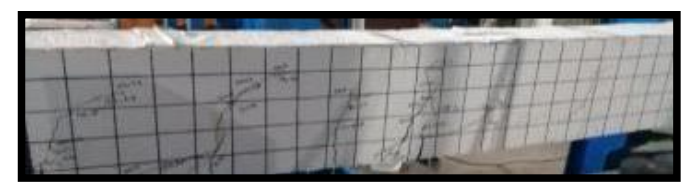

Fig. 14. Crack and Crack pattern 
From figure 14, a crack occurred in the middle area of the span extending to the direction of the press.

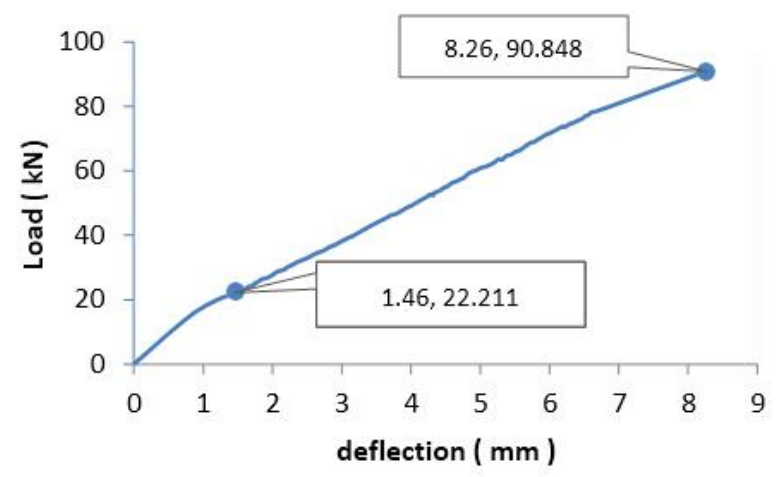

Fig. 15. Load-Deflection curve for lap-splice 30db

In Figure 15, curve of load relations - against beam deflection was obtained from BN 30db. The position of the yield reinforcement was obtained by comparing the recorded strain values, at $\mathrm{P}$ at $22.211 \mathrm{kN}$, the deflection value was $1.46 \mathrm{~mm}$, while at $\mathrm{P}$ at $90.848 \mathrm{kN}$, the ultimate deflection value was $8.26 \mathrm{~mm}$ and the reinforcement had not yielded, so there was no force over the reinforcement.

When the ultimate $P$ load was $90.848 \mathrm{kN}$, the concrete strain was 0,0009. SNI 2847: 2013 for analyzing the ultimate load data was taken at $c=0.003$, but the ultimate test results had not been obtained at a value of 0.003 , so the loading through pumping the hydraulic jack was stopped when the monitor data showed a decrease in data. The collapse that occurred in the beam was the failure of the transfer of force on the joint so that the strain value was not reached.

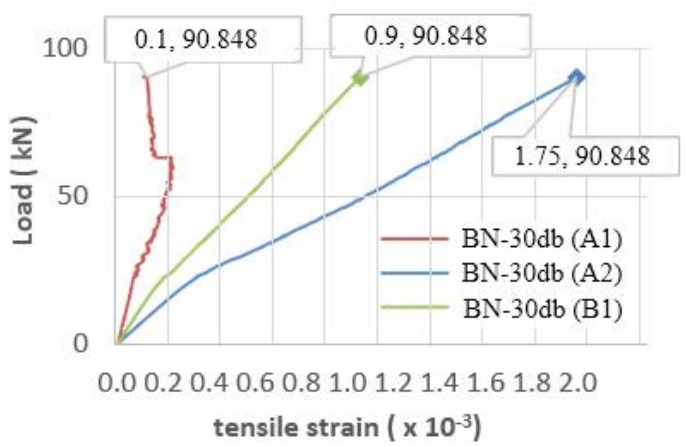

Fig. 16. Load - tensile strain for beam specimens ( BN- 30db)

From Figure 16, a curve of the load-strain relationship for the lower longitudinal reinforcement was obtained, when $P$ load of $90.848 \mathrm{kN}$ with A1 tensile strain had a strain value $s$ of 0.0001 , A2 had a strain s of 0.0017 and B1 had a strain value s of 0,0009 . Theoretically, the strain value A1 \& B1 should be the same but the difference in the values of A1 \& B1 indicated a style transfer failure.

\subsubsection{Concrete beam with splice length $40 \mathrm{db}(\mathrm{BN}-40 \mathrm{db})$}

In the beam BN-40db, the first crack occurred when the load reached $10,332 \mathrm{kN}$. The test results obtained a maximum load value of $124,804 \mathrm{kN}$. 

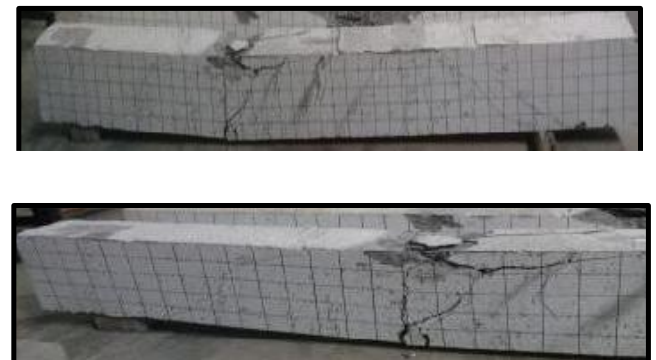

Fig. 17. Crack and Crack pattern ( $\mathrm{BN}-40 \mathrm{db})$

In Figure 17, it can be seen that the collapse occurred in the beam joint area. The first crack in the beam started from the bottom fiber in the area where the concrete was pulling along with the increase in load where the cracks increased and the crack spread to the compressed area.

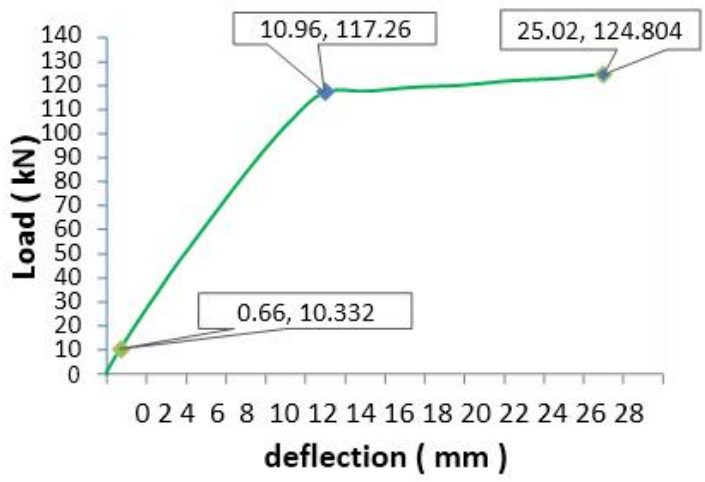

Fig. 18. Load-Deflection curve

In Figure 18, a curve of load-deflection relationships was obtained for the lower longitudinal reinforcement. The position of yield reinforcement was obtained by comparing the strain value recorded, at $P$ of $10,332 \mathrm{kN}$, had a deflection value of $0.66 \mathrm{~mm}$, while at $P$ of $117.26 \mathrm{kN}$, it had deflection value of $10.96 \mathrm{~mm}$ and at $\mathrm{P}$ of $124.804 \mathrm{kN}$, it had the ultimate deflection amounting to $25.02 \mathrm{~mm}$. When $\mathrm{P}$ was $10,332 \mathrm{kN}$, it had a concrete strain of 0,0001 and when the ultimate $\mathrm{P}$ load was 124,804 , the concrete strain $\mathrm{kN}$ was 0,003 .

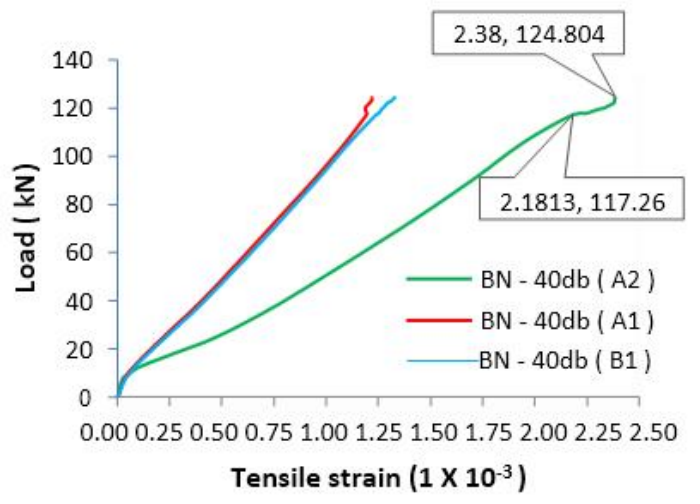

Fig. 19. Combined Load-Tensile strain curve

In figure 19, a curve of combined load relationship was obtained when the maximum $\mathrm{P}$ load of $124.804 \mathrm{kN}$ tensile strain with A1 had a value of $\mathrm{s}$ of 0.0017 , while A2 had a value of $\mathrm{s}$ of 0.00238 and B1 had a strain of 0.0013 . 
Table. 1. Correlation bond strength with splice length

\begin{tabular}{lccccc}
\hline Specimens & $\boldsymbol{P}(\mathbf{k N})$ & $\boldsymbol{l}_{\boldsymbol{d}}(\mathbf{m m})$ & $\mathbf{f}_{\boldsymbol{c}}(\mathbf{M P a})$ & $\mathbf{d}_{\mathbf{b}}(\mathbf{m m})$ & $\boldsymbol{\mu}(\mathbf{M P a})$ \\
\hline $\mathrm{BN}-0$ & 115.46 & - & 27 & 16 & - \\
\hline${\mathrm{BN}-30 \mathrm{~d}_{\mathrm{b}}}^{\mathrm{BN}-40 \mathrm{~d}_{\mathrm{b}}}$ & 90.848 & 480 & 27 & 16 & 3.77 \\
\hline
\end{tabular}

Seen in table. 1 above, the bond stress value of each specimen, BN-30db had bond stress value of $3.77 \mathrm{MPa}$, and $\mathrm{BN}-40 \mathrm{db}$ the bond stress was $3.88 \mathrm{MPa}$. The bond stress was attached to BN$40 \mathrm{db}$, up $2.92 \%$ against BN-30db.

\section{Behavior Comparison of the Test Objects}

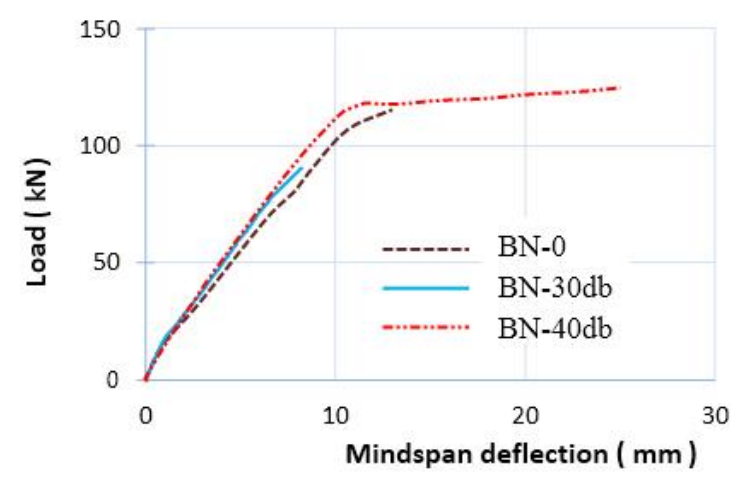

Fig. 20. Combined Load-Deflection curve

The behavior of each specimen was loaded until it reached the maximum load so that it had the amount of deflection that occurred until the collapse occurred. BN-0 had sufficient deflection after peak loads due to the effect of slippage that caused the reinforcement to stretch with the cost strain of the board.

Table. 2 Results Comparison of beam conditions (P- )

\begin{tabular}{ccccccc}
\hline \multirow{2}{*}{$\begin{array}{c}\text { Kondisi } \\
\text { Balok }\end{array}$} & \begin{tabular}{c} 
Balok BN-0 \\
\cline { 2 - 7 }
\end{tabular} & \multicolumn{2}{c}{ Balok BN-30d } \\
$\mathbf{( k N})$ & $\begin{array}{c}\text { Lendutan } \\
(\mathbf{m m})\end{array}$ & $\begin{array}{c}\text { Beban } \\
(\mathbf{k N})\end{array}$ & $\begin{array}{c}\text { Lendutan } \\
(\mathbf{m m})\end{array}$ & $\begin{array}{c}\text { Beban } \\
(\mathbf{k N})\end{array}$ & $\begin{array}{c}\text { Lendutan } \\
(\mathbf{m m})\end{array}$ \\
\hline First Crack & 14.76 & 0.86 & 22.211 & 1.46 & 10.332 & 0.66 \\
\hline First Yield & 106.96 & 10.64 & 90.848 & 8.26 & 117.26 & 10.96 \\
\hline Ultimate & 115.46 & 16.41 & 90.848 & 8.26 & 124.804 & 25.02 \\
\hline
\end{tabular}

\section{Maximum load received by the beam}

The BN-0 beam (beam without splice length) had a bending capacity of $115.46 \mathrm{kN}, \mathrm{BN}-30 \mathrm{db}$ had a flexural capacity of $90.848 \mathrm{kN}$, and BN-40db had a bending capacity of $124.804 \mathrm{kN}$. The difference in $\mathrm{P}$ values was possible because of the unevenness of the strength of the concrete associated with the aggregate distribution of the beams, which caused a difference in the maximum $P$ value of the beam. 


\section{Displacement ductility}

The ductility observed in this study was displacement ductility. The displacement ductility is a condition of the comparison between the maximum displacement of the beam and the displacement that occurs when the structure melts. The ductility of each test object can be seen in Table. 3

Table. 3 Displacement ductility $\left(\boldsymbol{\Delta}_{\mathbf{6}}\right)$

\begin{tabular}{cccccc}
\hline Benda Uji & $\mathbf{P}_{\text {leleh }}$ & $\mathbf{P}_{\mathbf{m a x}}$ & $\boldsymbol{\delta}_{\mathbf{y}}(\mathbf{m m})$ & $\boldsymbol{\delta}_{\mathbf{u}}(\mathbf{m m})$ & $\boldsymbol{\delta}$ \\
\hline BN-0 & 106.96 & 115.46 & 10.64 & 16.41 & 1.54 \\
\hline BN-30d $\mathrm{d}_{\mathrm{b}}$ & 90.848 & 90.848 & 8.26 & 8.26 & 1.00 \\
\hline BN-40d & 117.26 & 124.804 & 10.96 & 25.02 & 2.28 \\
\hline
\end{tabular}

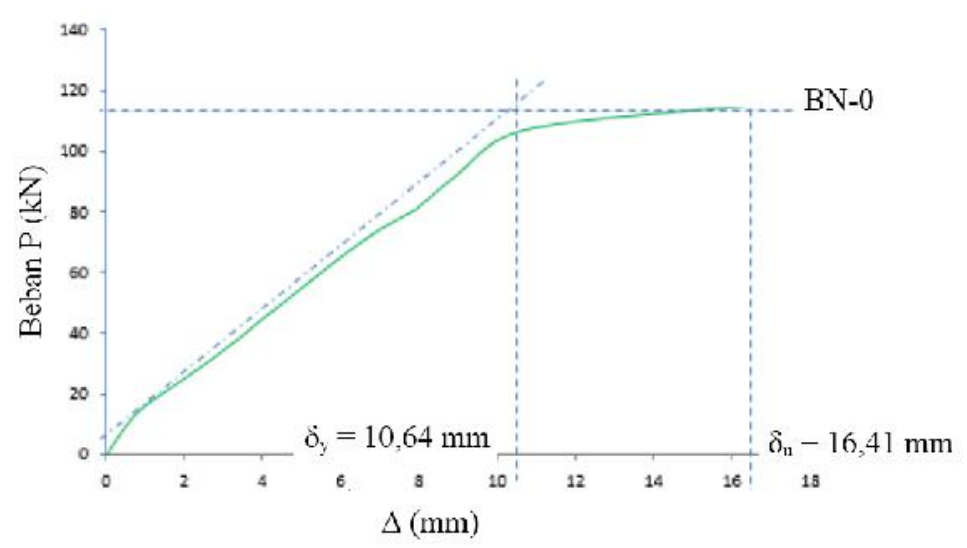

Fig. 21. Displacement Ductility Calculation (BN- 0)

The displacement ductility in the $\mathrm{BN}-0$ beam was 1.54 . On the $\mathrm{BN}-30 \mathrm{db}$ beam the displacement ductility was 1.00 and on the $\mathrm{BN}-40 \mathrm{db}$ beam the displacement ductility was 2.28 . The percentage of ductility of beam displacement BN-0 to BN-30db had decreased by $35 \%$, but the percentage of ductility of $\mathrm{BN}-0$ transfer to $\mathrm{BN}-40 \mathrm{db}$ had increased by $48.05 \%$. The increase and decrease in displacement ductility could be influenced by the cross-sectional properties of the beam, namely increasing and decreasing the concrete strain, increasing the concrete bonding stress and the amount of compressive reinforcement.

\section{Conclusion}

Based on the results of research and discussion, the conclusions are presented as follows:

1. Lack of long stretch caused failure of force transfers on tensile reinforcement which resulted in failure of the beam so that it had a low displacement ductility in order to reinforce the structure

2. The crack pattern that occurred in the beam of the test object with the joint on the tensile reinforcement was the spread of crack concentration around the joint.

3. BN-30db flexural capacity decreased $21.36 \%$ to $\mathrm{BN}-0$ and flexural capacity at BN-40db increased $8.09 \%$ to $\mathrm{BN}-0$

4. Percentage of voltage attached to BN-40db increased by $2.92 \%$ against BN-30db.

5. Percentage of BN-30db Ductility decreased $35 \%$ to BN-0 and displacement ductility at BN$40 \mathrm{db}$ increased $48 \%$ to $\mathrm{BN}-0$. Based on the testing, the length of $\mathrm{BN}-40 \mathrm{db}$ was able to develop the ability to achieve yield loads with beam ductility of 2.28 so that the length the minimum channel distribution was $l d=40 \mathrm{db}$. 


\section{Acknowledgement}

I would like to thank my two principal advisors, Ilham Nurhuda, Ph.D. and Prof. Dr. Antonius who always gave direction, guidance, and patience in guiding the writers.

\section{References}

[1] Anonim, 2013. SNI-2847-2013. Building Code Requirements for Structural Concrete. National Standardization Agency of Indonesia, 1-265. Bandung.

[2] Abdel-Kareem, A. H., Abousafa, H., \& El-Hadidi, O. S. (2015). Effect of Transverse Reinforcement on the Behavior of Tension Lap Splice In High-Strength Reinforced Concrete Bes. Slovak Journal of Civil Engineering, 23(3), 1-8. https://doi.org/10.1515/sjce-2015-0011.

[3] Alavi-Fard, M., \& Marzouk, H. (2004). Bond of high strength concrete under monotonic pull out loading. Magazine of Concrete Research, 56(9), 545-557.

[4] Nuroji. (2004). Experimental study of the bonds between concrete and reinforcement at high quality concrete. Media Komunikasi Teknik Sipil, 12(3), 27-37.

[5] Hamad, B. S. (2002). Evaluation of the role of transverse reinforcement in confining tension lap splices in high strength concrete. Materials and Structures, 35(248), 219-228. https://doi.org/10.1617/13786.

[6] Hassan, T. K., Lucier, G. W., \& Rizkalla, S. H. (2012). Splice strength of large diameter, high strength steel reinforcing bars. Construction and Building Materials, 26(1), 216-225. https://doi.org/10.1016/j.conbuildmat.2011.06.013.

[7] Mousa, M. I. (2015). Flexural behaviour and ductility of high strength concrete (HSC) beams with tension lap splice. Alexandria Engineering Journal, 54(3), 551-563. https://doi.org/10.1016/j.aej.2015.03.032.

[8] Park, R. and Paulay, T., 1975, Reinforced Concrete Structures, John Wiley and Sons. Inc., New York.

[9] Nuroji. 1996. Mechanical behavior of concrete and reinforcement bonds on high quality concrete due to static load. Thesis. Pascasarjana Universitas Institut Teknologi Bandung. 